\title{
Malaysian Perception Toward Foreign Tourists in Malaysia
}

\author{
*Ravis Chena Alvarez ${ }^{1}$ and Siti Nor Atikah ${ }^{2}$ \\ ${ }^{1)}$ Graduate Student of Geography Education, Universitas Negeri Padang, Indonesia \\ e-mail: ravischena96@gmail.com \\ 2) Student of Geography, Malaya University, Malaysia \\ e-mail: sitiatikah81@gmail.com
}

*Corresponding Author, Received: September14, 2018, Revised: October 21, 2018, Accepted: December 05, 2018

\begin{abstract}
The purpose of the study was to collect, process, analyze and describe the perception of Malaysian towards foreign tourists in Malaysia. This research is a descriptive analysis. Data collected using observation, interview, and documentation techniques. Data analysis in the study was carried out using data reduction techniques, data interpretation and conclusion drawing. The results show that 1). Public perception of foreign tourists in Malaysia shows that Malaysians are very supportive of foreign tourists coming to Malaysia. 2). Positive and negative impacts of foreign tourists coming to Malaysia; the positive impact, with the presence of tourists can increase Malaysia's foreign exchange and advance the country. As for the negative impact, Malaysians also negatively perceive black tourists such as from Bangladesh, Sri Lanka who usually bring problems in Malaysia such as narcotics and crime.
\end{abstract}

Keywords:Community Perception, Tourists, Malaysia

\section{Introduction}

Malaysia is the 43rd most populous country and the 66th largest land country in the world, with a population of approximately 27 million and has an area with various ethnicities, languages, cultures, religions and food. Administratively, Malaysia, which is a federated country, is divided into 13 states and 3 partnership territories. Indigenous people, in this case, are called Malays and non-natives are called non-Malay tribes. Malay tribe is a name that refers to a group whose main characteristic is the narration of Malay. Malays live in much of Malaysia, the east coast of Sumatra, around the coasts of Kalimantan, southern Thailand, and small islands stretching along the Malacca Strait and Karimata Strait. Tourism is one of the largest industries in the world that is growing rapidly (Moli, 2011). Tourism is a very important economic centre because the income from these activities is very high (Ghanapala, 2015). Tourism is considered as an industrial sector that is able to develop the independence of a country and is a driver of growth in other sectors (Nugraha et al., 2013; Hermon, 2016a). This makes tourism an icon of development in a country whose development is increasing.

Tourism touches various aspects of people's lives, including socio-economic, socio-cultural and environmental aspects. In addition, according to Tjitroresmi (2003) that the tourism industry is not only related to tourist attractions, but also related to other industries, such as hotels, restaurants, transportation (land, sea and air) and other industrial products. As it was previously explained, tourism is a "new" commodity for countries in the world, especially for developing countries. Where at the time the various economic sectors of developing countries were focused on various activities of enrichment and exploration of natural wealth. In general, when developing countries must develop their economic sectors to get better state 
income, tourism is the right choice where every country will always have the distinctive characteristics and attractiveness for foreign and domestic tourists (Hermon et al., 2018). Tourism has a very important role in improving people's lives, it can be seen in terms of economic, social or cultural aspects. In terms of economics, Malaysian tourism has an important role in increasing people's income and increasing foreign exchange reserves. In terms of social tourism, Malaysia can bridge the distance and eliminate differences, so as to foster a sense of brotherhood between ethnicity, race and religion. Whereas if viewed in terms of culture, tourism Malaysia has a role in introducing various cultural customs and customs that exist in society in a certain area and also to strengthen the unity and integrity of the nation.

Perception can be interpreted as a person's interpretation of an information based on the individual's understanding of an object. Thus it is possible to occur different perceptions about an object that depends on the level of understanding and interpretation of each individual against the object. Meanwhile, according to Sugihartono et al (2007). Tourists are someone who enters a foreign country for any purpose and purpose, provided that it is not for permanent residence or for regular efforts to cross the boundary and spend money in the country he visits, the money is not in the country but in other countries.

\section{Method}

Based on the problems studied in this study and the objectives to be achieved are to find out the perception of the Malaysian people towards foreign tourists in Malaysia. This research is a type of descriptive research type research with qualitative data from primary and secondary data. Descriptive research is not to test the correctness of the hypothesis but only describes the existence of a variable, symptom or condition (Hermon et al., 2008). This research was conducted in several places in Malaysia such as at the University of Malaya, Jamek Mosque, Damansara, E Curve Mall, Kuala Lumpur City Council (DBSA), Batu Caves Temple, Kajang, Bukit Bintang, Putrajaya Mosque, Putrajaya Wetland Park. The research was conducted with a span of time between July 7th - 12nd, 2018. Data collection was carried out by interview, observation and documentation. The informants in this study were students of Malaya University, Lecturers of Malaya University, grab drivers, as well as indigenous people who were found in tourist attractions in Malaysia that researchers considered having the competence in providing information about the expected research data, namely the perception of Malaysian society towards foreign tourists in Malaysia.Data analysis was carried out with data reduction techniques. Data reduction is an electoral process, focusing attention on simplification, abstracting, rough data transformation that arises from records in the field (Miles and Huberman, 2015). The steps were taken in data reduction by sharpening analysis, categorizing or categorizing into each problem briefly, directing, removing unnecessary and organizing data so that they can be withdrawn and verified. The reduced data include all data regarding research problems. Reduced data will provide a more specific picture and make it easier for researchers to conduct further data collection and find additional data if needed. The longer the researcher is in the field, the more data will be, the more complex and complicated. Therefore, data reduction needs to be done so that data is not piled up so as not to complicate further analysis. Data interpretation is data obtained from searching for the meaning contained in it and then presented using words and sentences that are easy to understand, then drawing conclusions. In this research, the researcher tries to get information about the variables under study, so the data obtained from the field that has been collected and analyzed draws conclusions and finally will be the result of the research.

\section{Results and Discussion}

Tourism is one of the important sectors in the economy of the Malaysian State which later became the fifth largest sector in Malaysia in 2010 based on the State Design Unit. Although at the beginning of independence the kingdom had not yet glanced at this sector, because at that time the kingdom was more focused on developing the country's infrastructure and resisting threats from communists (Mahmud, 2009). It was only in the 70 s that the tourism sector experienced a positive development, this was marked by the arrival of tourists to Malaysia which increased from 23,000 in 1961 to 77,000 in 1970. The latest data in 2005 tourist arrivals to Malaysia again increased where as many as 16, 4 million people were recorded as coming 
to Malaysia. Development is defined as a process or a way to make it progress, good, perfect and useful (Poerwadarmita, 2003). Tourism development begins with an inventory of tourist treasure sources identifying to make realistic evaluations of existing or potential this right is an integral part of the preliminary and planning stages.

Development is to advance and improve or improve existing ones (Lanya, 1995).A, Yoeti in his book "Introduction to Tourism Science" in 1985 that the term tourist attraction is more commonly used, namely everything that attracts people visiting a particular area. Meanwhile, according to Nyoman S. Pandit in his book "Science of Tourism" in 1994, defining tourist attraction as everything that is interesting and valuable to visit and see. Santoro (2001; Hermon, 2016b; Hermon, 2017) also put forward several limitations on tourist attraction with several criteria in a tourist attraction, namely: 1) Existence of resources that cause pleasure. 2) There is good accessibility to reach tourist attractions. 3) There are specific or specific characteristics. 4) There are supporting facilities and infrastructure that can serve the needs of tourists who come. 5) Natural attractions that have high attraction due to the natural beauty of mountains, sand, forests, and so on. 6) Tourism objects have a high attraction because they have special values in the form of art attractions in a tourist attraction created by humanity in the past.

Public perception of foreign tourists in Malaysia. Kuala Lumpur has a tourist destination that is good enough to attract foreign tourists to come to Malaysia. With very rapid progress, Kuala Lumpur is one of the tourist destinations that must be visited. Tourists from various regions in Malaysia and abroad such as from Indonesia, China, India, Pakistan, Bangladesh, England etc. came to enjoy a pleasant holiday in Kuala Lumpur, Malaysia. There are a lot of tourist spots in Kuala Lumpur that are famous to foreign countries. All this time what is known to people is The Petronas twin towers, whereas in addition to the Petronas twin towers many other tourist destinations in Malaysia such as Kuala Lumpur City Center (KLCC), Langkawi, Bukit Bintang, Putrajaya Malaysia Bridge, Batu Caves Temple, Taman Wetland Putrajaya, Masjid Jamek Malaysia, Aquaria KLCC, Genting Highland, Penang National Park and others. Indicates that Malaysian people are very supportive of the presence of foreign tourists to Malaysia. Because the presence of foreign tourists to Malaysia can make the country of Malaysia indirectly increasingly known in the international arena, especially in the field of tourism. With a large number of foreign tourists coming to Malaysia, it will also make the Malaysian government and related stakeholders increasingly spur their enthusiasm to increase the existing tourism potentials. Because Tourism has a very important role in improving people's lives, it can be seen from an economic, social or cultural perspective. In terms of economics, Malaysian tourism has an important role in increasing people's income and increasing foreign exchange reserves. In terms of social tourism, Malaysia can bridge the distance and eliminate differences, so as to foster a sense of brotherhood between ethnicity, race and religion. Whereas if viewed in terms of culture, tourism Malaysia has a role in introducing various cultural customs and customs that exist in society in a certain area and also to strengthen the unity and integrity of the nation. Positive and negative impacts of foreign tourists visiting Malaysia. With tourists can increase Malaysia's foreign exchange and advance the country. Because tourists who visit will benefit the Malaysian state itself. Examples such as tourists who shop will benefit the Malaysian state and from tourists who visit it will further facilitate the promotion of tourism objects in Malaysia.

Furthermore, tourists visiting will help the government to increase and promote tourism objects in Malaysia. Malaysians also negatively perceive black tourists like those from Bangladesh, Sri Lanka who usually bring problems in Malaysia such as narcotics and crime. Because not all who visit on behalf of tourism come to Malaysia with good intentions, there are also some of the tourists who come to Malaysia that have a bad impact on the country of Malaysia. Therefore the Malaysian government must further improve the supervision and security of tourists who come to Malaysia, so as not to damage the comfort of other tourists and also to maintain the good name of the Malaysian state.

\section{Conclusion}

Based on the results of the research that the author got from the data of observation, interviews and documentation studies as well as the discussion above, the conclusions the authors get from research on the perception of Malaysian society towards foreign tourists in Malaysia are as follows: (1) Malaysians are very supportive of foreign tourists travelling to Malaysia; (2) The presence of tourists can increase the country's 
foreign exchange and advance the country of Malaysia; (3) Tourists are interested in travelling to Malaysia due to cheap prices for goods in Malaysia such as bags, shoes and electronic goods; (4) The negative impact of tourists in Malaysia can increases such as crime, drug trafficking (narcotics).

\section{References}

Ghanapala, W.K.A. 2015. Tourists Perception and Satisfaction: Implications for Destination Management. American Journal of Marketing Research. 1(1). 7-19.

Hermon, D., Khairani., Daswirman., S. Karim., Dasrizal., and Triyatno. 2008. Metode dan Teknik Penelitian Geografi Tanah: Aplikasi Instrumen dan Acuan Penelitian Geografi Fisik. Yayasan Jihadul Khair Center.

Hermon, D. 2016a. The Strategic Model of Tsunami Based in Coastal Ecotourism Development at Mandeh Regions, West Sumatera, Indonesia.Journal of Environment and Earth Science. Volume 6.

Hermon, D. 2016. Mitigasi Perubahan Iklim. Rajawali Pers (Radjagrafindo).

Hermon, D. 2017. Climate Change Mitigation. Rajawali Pers (Radjagrafindo).

Hermon, D., Y. Suasti., Ernawati., Afdhal., and H. Edial. 2018. Geografi: Geografi untuk SMU. Jurusan Geografi Universitas Negeri Padang.

Kusmayadi, E.S. 2000. Metodologi Penelitian dalam Bidang Pariwisata. Jakarta: PT. Gramedia Pustaka Utama.

Lanya. 1995. Buku Pedoman Kerja Pariwisata (BPKM) Mata Kuliah Dasar-Dasar Pengembangan Wilayah. Fakultas Pertanian UNUD. Denpasar.

Mahmud, N. A. N. 2009. Konfrontasi Malaysia Indonesia. Bangi: Universiti Kebangsaan Malaysia.

Maha, G., I. K. Hariyana and I.G. A. Okta. 2015. Persepsi Masyarakat Terhadap Pengembangan Kawasan Goa Peteng Sebagai Daya Tarik Wisata di Desa Jimbaran Kuta Selatan Kabupaten Badung. Jurnal Destinasi Pariwisata, Vol 3, No1, Hal, 27.

Miles dan Huberman. 2015. Analisis Data Kualitatif Buku Sumber tentang Metode-Metode Baru. Jakarta: UI Press.

Moleong, L. J. 2002. Metodelogi Penelitian Kualitatif .Bandung: Remaja Rosdakarya.

Moli, G.P. 2011. Community Based Eco Cultural Heritage Tourism for Sustainable Development in the Asian Region: a Conceptual Framework. International Journal of Social Ecology and Sustainable Development (IJSESD), 2(2), 66-80.

Nugraha, H.P., Indarjo, A. and Helmi, M. 2013. Studi Kesesuaian dan Daya Dukung Kawasan untuk Rekreasi Pantai di Pantai Panjang Kota Bengkulu. Journal of Marine Research, 2(2), 130-139.

Poerwadarminta. W.J.S. 2003. Kamus Umum Bahasa Indonesia. Jakarta: Balai Pustaka

Sidiq, H. J and R. S.Sofro. 2015. Persepsi Masyarakat terhadap Wisatawan di Candi Muara Takus Kabupaten Kampar. Jom FISIP, Vol 2, No 2, Hal, 1-4.

Suwantoro, G. 2001. Dasar-Dasar Pariwisata. Penerbit Andi. Yogyakarta.

Tjitroresmi, E. 2003. Peran Industri Kepariwisataan dalam Perekonomian Nasional dan Daerah. Jakarta: P2ELIPI.

Wahab, S. 1992. Manajemen Kepariwisataan.Jakarta: PT. Pradnya Paramita.

Walgito, B. 1999. Psikologi Sosial (Suatu Pengantar).Yogyakarta: CV. Andi Offset.

Yoeti, O. A. 1992. Pengantar Ilmu Pariwisata.Bandung: Angkasa Offset. 